\title{
North Korea's 2018 Foreign Policy U-turn: Using Levels of Analysis to Understand Kim Jong-un's Rationale
}

\begin{abstract}
Andrew S. Millard
In March, 2018, the Democratic People's Republic of Korea's (DPRK) unexpectedly announced that it would re-start negotiations with the United States (US) with regards to nuclear weapons development, signaling an unexpected, but significant, $\mathrm{U}$-turn in its foreign policy. Whilst many academics have put this down to the effect of increased sanctions on the DPRK, I argue that leadership changes in both the US and Republic of Korea (RoK) were the main factor, since these leadership changes brought about foreign policy changes in their respective states. Changes at the system and unit level do not appear to be significant to the DPRK's foreign policy on their own, whereas shifts at the individual level have been more drastic than usual. This allowed the DPRK's leadership to take advantage of the situation, at a point when the US and RoK had domestic disunity. As such, in this paper I analyze the main events at the three major levels; system, unit, and individual levels, using the IR theory of classical realism to support the thesis.
\end{abstract}

Key Words: Foreign policy, Policy shift, Leadership, Domestic disunity, Individual level analysis

\section{INTRODUCTION}

In March, 2018, the Democratic People's Republic of Korea's (DPRK) announced that it would re-start negotiations with the United States (US) with regards to nuclear weapons development, signaling an unexpected, but significant, U-turn

\footnotetext{
* Andrew S. Millard was awarded his Doctorate in International Studies from the Graduate School of International Studies, Pusan National University, in 2016. He is now an assistant professor at Busan University of Foreign Studies and teaches courses on politics, international politics, diplomacy and the European Union. He has lived in South Korea for almost 15 years and can speak Korea well. He has published several articles related to security issues on the Korean peninsula, as well as papers that focus on Korean domestic politics.
}

The Korean Journal of International Studies Vol.18, No.1 (April 2020), 59-86 
in its foreign policy. Indeed, since the end of the Cold War, and in particular since the death of former leader Kim Il-sung, the DPRK has maintained an aggressive approach to foreign policy, one that has only increased under Kim Jong-un. That is what made the sudden change in policy so intriguing, in particular after the heightened tensions in late 2017, including a war of words between Chairman Kim and President Trump. Whilst it is a hugely positive step forward for peace and stability in the region and beyond, one big question remains, Why?

This paper aims to understand the reasons behind Kim Jong-un's sudden change in policy. It looks at system-level events that occurred, along with the domestic changes in various states, and finally focuses on the individual level. Based on official North Korean statements and reliable media sources on North Korean policy-making, the paper also determines why the DPRK began to undertake such a radical shift in policy, and the implications of that sudden shift for future negotiations. By analyzing these factors, this will give a clear overview of what factors were most influential in pushing Kim to suddenly open up to international diplomatic efforts in 2018 after a period of intense diplomatic stand-off.

After an overview of literature on levels of analysis and brief review of classical realism, the first section looks at the system level and discusses how the balance of power has shifted in favor of China's growth, which not only impacts the influence that the US has in the region, but also plays a major role in giving the DPRK room to maneuver in its foreign policy based on its relationship with China. With a shifting balance, the DPRK will be able to pursue its own objectives with more leeway. The section also looks at Russia's position and influence on the DPRK, as well as how Russia's own foreign policy may impact the US.

Following on, the second section focuses on the unit level of several states that impact North Korea's economy and security. The domestic political situations of South Korea, the US, Japan and the DPRK are analyzed and how those situations have impacted the DPRK's foreign policy. The third section then finishes by looking at how changing leadership has influenced policy-making, in particular in the US and RoK. The changing Presidents, the relationships between President Trump and Chairman Kim, and the pro-North Korean, progressive tendencies of President Moon in the RoK are all factors that have occurred at the same time and have been absent in previous years, thus making the individual level the most striking factor in the changing foreign policy trajectory of the DPRK in 2018.

In this paper, it will be shown through systematic comparison that whilst system and unit level changes did occur, the individual level changes in several states combined to allow the DPRK more freedom to follow its national interest with regards to defense in 2018. The criteria used is to analyze whether or not the 
changes that occurred at each level were consistent with general changes in previous years, or whether they occurred based on specific, unusual circumstances at that time, for example did the DPRK shift its policy-making rationale in order to appeal to the personal nature of the incumbent leaders in the US and RoK?

By analyzing the three levels before and after 2018 this paper will show which level saw the most significant changes. This will be highlighted by the fact that since 2019, with growing domestic discontent in both the US and RoK, friendly attitudes to the DPRK began to wane and the DPRK has again returned to its default, militaristic foreign policy including a return to missile testing. By understanding the rationale of the DPRK's leadership any future foreign policy changes will be understood more easily and negotiations can be carried out more objectively, namely if future deviations in 'standard' foreign policy are based on the desire within the DPRK for true reform or whether they are taking advantage of the favorable conditions presented. Simply put, it is crucial that other world leaders and states understand and realize Chairman Kim's tactics in order to negotiate effectively.

\section{LEVELS OF ANALYSIS THROUGH A REALIST LENS}

It should, from the outset, be made clear that this paper does not intend to redefine the concept of levels-of-analysis, nor argue that one particular level is more important than the other when we study international relations in general. Through this paper, I merely use the standard concepts of levels-of-analysis to understand why the DPRK made changes its in foreign policy in 2018. It is important to look at all three levels because, as Caporaso et al. $(1986,1)$ mention, "To construct a comprehensive theory of foreign policy no facet can be ignored, or easily held constant." Taking a slightly different approach, however, Singer $(1961,77)$ notes in his introduction, which level of analysis scholars choose to pursue "is ostensibly a mere matter of methodological or conceptual convenience." The predominant choice of analysis is the structural level, with the national, or unit, level also quite popular. The individual level, as preferred by classical realists, is somewhat underused, although this paper will see it as a major area of analysis.

Amongst the levels there are several newer ones that deserve mention, but will not be used in this paper, for example Hafner-Burton, Kahler and Montgomery (2009) study the growing importance of network analysis, and Jacobs $(2015,11)$ discusses the all-encompassing approach of all-level analysis, which he notes "encompasses and integrates all of the levels of international theory," in particular, focusing on "coercion, deterrence, and compellence." Buzan and 
Waever (2003) add the concept of Regional Security Complex (RSC) when studying international relations, with Soltani, Naji and Amiri (2014, 169) discussing how RSC "enables scholars to get better understanding of new structure of international politics," whilst also adding that RSC is different from the neorealist perspective in that "it rejects global level structure in neorealism and emphasizes regional level." Gleditsch and Hegre $(1997,297)$ focused their study on democratic peace theory and looked at the role of dyads in the system, but pointed out that "there has been little research at the system level and very little discussion about the links to the other levels."

This paper will focus its analysis of North Korean foreign policy on Waltz's (1959) "three images," the first image being the individual level, the second image the unit level and the third image the system level. The international level, or system level, is often considered as the most prominent level of analysis in international relations (Soltani, et al. 2014; Hafner-Burton, Kahler and Montgomery 2009; Singer 1961). The benefit of analyzing foreign policy on the structural level, according to Singer $(1961,80)$ is that "it is the most comprehensive of the levels available, encompassing the totality of interactions which take place within the system and its environment." However, he does objectively note that the system level analysis "exaggerates the impact of the system upon the national actors and, conversely, discounts the impact of the actors on the system" (ibid.). Soltani et al $(2014,167)$ agree with Singer, noting that scholars choosing to focus on system level analysis "have no choice but to ignore some details in favor of studying the whole." Tamaki $(2015,89)$ also points out that analysis using the system level "prevents us from asking questions such as the role of domestic coalition patterns in the formulation of foreign policies," citing religious, historical and ideological factors as ones which also need to be considered on the state level.

The unit level of analysis focuses on the role of the state, or as Waltz $(1959,80)$ puts it the way that "the people in it act." As such, for unit level analysis it is assumed that the people within the state are unified. Singer $(1961,82)$ also advocates for the use of unit level analysis, arguing that "it permits significant differentiation among our actors in the international system," although he does then err on the side of caution by warning that such analysis could "lead us into the opposite type of distortion-a marked exaggeration of the differences among our sub-systemic actors" (ibid., 83).

The ideology of a state is also part of this analysis. Jacobs $(2015,13)$ suggests that there are three main theories to follow in state level analysis, namely "democratic peace, strategic culture, and revisionism." Of particular importance for this paper, given the undemocratic nature of the DPRK, is Jacobs advocacy of democracy as a means of preventing war, by eliminating the security dilemma 
(ibid., 14). This is quite a debatable sentence, given that Gleditsch and Hegre $(1997,297)$ concluded from their study on democratic peace that, "This is not tantamount to saying that democracies are more peaceful. Such a statement would require a more detailed analysis of the patterns of escalation and consideration of a wider set of wars." Nevertheless, there seems to be academic consensus that democracies and non-democracies have a higher possibility of conflict with each other (Gleditsch and Hegre 1997; Jacobs 2015).

The role of humans is one that must be accounted for in decision-making, especially given the role of human nature in classical realism. Waltz $(1959,16-79)$ talks in detail about the role that individuals play in foreign policy, discussing and analyzing human behavior in what he calls “The First Image.” Even though Waltz's analysis concentrates on the cause of war, it still provides valid arguments for how individuals decide general foreign policy, as is the purview of this paper. As such, the first image will be considered as a major level of analysis in the DPRK's foreign policy decision-making.

Rourke $(2008,65)$ asserts that individuals make foreign policy decisions that are "influenced by cognitive, emotional, psychological, and sometimes even biological factors, as well as by rational calculations." This is supported by Jacobs (2015, 22-23) who also discusses cognitive and emotional factors, but adds that "Individual's mental processes of perception, memory, judgment, and reasoning" are also key factors in individual decision-making processes. Whilst in modern democracies individuals may be somewhat constrained by domestic constitutions, as we shall see in this paper that is not always the case, nor is it the case in authoritarian systems. According to Mingst and Arreguin-Toft $(2017,185)$ there are three main ways for individual elites to have a major impact on foreign policy; firstly, "when political institutions are unstable, young, in crisis or collapsed", secondly, "when institutional constraints are limited", and thirdly, "when the issue or situation is peripheral, unusual, or ambiguous".

Using levels of analysis alone to understand the situation is not satisfactory and to support the first image view of Waltz this paper also applies a realist stance to international events. In Morgenthau's Politics Among Nations, he asserts that human nature plays a decisive role in determining the role of the state in the international arena. Morgenthau and Thompson $(1985,166)$ state, "Realism maintains that universal moral principles cannot be applied to the actions of states," and that whilst the state should uphold morals it should not let those morals stand in the way of national interests. As such, in power politics, the statesman is the key player and driver of the state and the state will be driven by the statesman's own nature.

Saint Augustine and Machiavelli both focused on the roles of leaders, with 
Augustine having a "conviction that humankind is incapable of establishing a truly just political order" (Loriaux 1992, 407) and Machiavelli is well-known for his concept that leaders should choose rule of fear over love. Each theory proposes a more negative view of the human role in leadership, but it supports the core idea of this paper that a state is lead predominantly by the leader and the decisions made can take the state in unexpected directions. Machiavelli suggested that rational decisions are made when there are fewer options to choose from, yet it can be said that in the case of the DPRK there are several options that it could take, which Machiavelli would argue makes Kim susceptible to irrational decisions.

Waltz, in his 'third image' also expressed that the unit level only had a "secondary impact on state behavior" (ibid.), although to be clear, Waltz's third image advocated the system-level as having the biggest impact. Either way, the idea that humans, whether rational or not, decide the direction of foreign policy is vital for this paper's core thesis that in 2018 the individual characteristics and policies of leaders in several countries all created the ideal atmosphere for a shift in the DPRK's foreign policy. This will be discussed in the following sections.

\section{SYSTEM LEVEL ANALYSIS}

Waltz's 'Third image' reflects the anarchic state of global politics. In a very state-centric statement about how states can defend themselves from conflict with others, he writes "to achieve a favorable outcome from such conflict a state has to rely on its own devices, the relevant efficiency of which must be its constant concern" $(1959,159)$. In simple terms, all states must be prepared to defend themselves against the threat of more powerful states in a world where a global governance system does not exist. Whilst the Liberalists would argue that modern Intergovernmental Organizations (IGOs) like the United Nations (UN) acts as arenas for diplomatic resolution, this paper will follow Waltz's neorealist view that, as of yet, there is no efficient supranational global system that can restrain states in their pursuit of power and influence.

As mentioned earlier with Singer's citation, the system level is a comprehensive overview of interactions within the international system. During the 1990s the end of the Cold War saw a massive shift in global order, with the US ascending to global hegemon and the former Union of Soviet State Republics (USSR) dissolving into multiple independent states, with Russia struggling to overcome massive economic decline. Simultaneously, the European Union (EU) pushed for ever-closer union by drafting a timetable to establish the single currency, as well 
as by facilitating-financially, politically and socially-the transition of former soviet bloc states to democratic, free market states capable of converging with western European economies. As such, the EU was focused more on its own neighborhood, rather than global foreign affairs. All the while, a giant in the East was beginning to wake from an extended hibernation. The opening up of China in the early 1980s was starting to take effect and by the 1990s trade was starting to increase. However, it was not until the 2000s that China really burst on to the international politics arena, and even then, it was held back by its relative weak influence in foreign affairs. That has since changed, and a new world order is on the horizon.

China has patiently been rebuilding itself over the past few decades and is approaching the title of 'superpower.' According to the definition by Dukes (2002, 1), "A 'superpower' must be able to conduct a global strategy including the possibility of destroying the world; to command vast economic potential and influence; and to present a universal ideology," which effectively means that a state must possess the economic wealth to pursue a foreign policy of global domination that it can sustain through military and ideological means. The US has clearly held that mantle since the collapse of the USSR, but, as mentioned, China is now on the cusp of such status, not only because of its growing economic status, but because over the past few years it has embarked on a territorial push in the South China Sea, as well as established economic institutions that have much bigger global reach, for example becoming the major stake holder in the Asian Infrastructure Investment Bank (AIIB). In doing so, by changing the world order it has allowed states like the DPRK to adjust their foreign policies accordingly. With China as its main ally, the growth of China and any change at the system level will have huge implications for the North Koreans.

Economically, China has outgrown virtually all states in recent years. A report by the Congressional Research Service (CRS) (2019) shows that China has, with the exception of 1989 and 1990, seen real annual GDP growth rates above 6\% from 1983 to 2017, and predictions estimate that up until 2024 the growth rate will decline only gradually to 5.5\%. In comparison, figures from Statista show that the US growth rate has never exceeded 4\% since 2001, and since 2005 has not surpassed $3 \%$ annual growth. To put that in to context, a report by $C N N$ entitled 'There are more wealthy Chinese than Americans for the first time', indicates that China is gaining ground not only on the US, but also in global economic terms, The report states, "China holds claim to a growing piece of the pie, replacing Europe as the principal engine of global wealth growth.” With Xi's 'One Belt One Road' policy in full swing, this will only continue.

Furthermore, through the creation of the Asia Investment Infrastructure Bank (AIIB) in 2015, China has also claimed a stake in the global economic system, 
which up until now was dominated by the western institutions of the World Bank and International Monetary Fund (IMF). So threatened by the AIIB, the US attempted to persuade its major allies not to join the AIIB when it started (see Shephard, 2016), but to no avail.

However, China also has several points of weakness. The pro-democracy movement in Hong Kong in 2019 may have a substantial impact on China's global position if the situation is not fully resolved. In November, 2019, President Trump signed in to US law the bill passed by Congress that will see Hong Kong's special trade status with the US reviewed on an annual basis based on Beijing's actions towards the former British territory. The same legislation also asserts that if human rights are violated then the US will apply sanctions against China. This is a case of the US putting its foot down in the region in order to maintain a level of authority, but with potentially bigger consequences. In addition, to the Hong Kong issue, China's rapid growth may also prove to be its downfall. Economists have been discussing the potential of an economic crisis in China for several years. Whilst one has not occurred, some remain pessimistic. Schuman, for example, writing for Bloomberg ('Forget the Trade War. China is Already in Crisis'), states "This crisis is about China's economic future and whether or not it can manage the structural transformation necessary to propel the economy into the ranks of the world's most advanced." Any crisis would, of course, push the DPRK's current foreign policy off track as Beijing would not be able to support the DPRK in any meaningful way.

Militarily, the US still holds the major advantage, although China is also rapidly expanding its own military capabilities, including the building of aircraft carriers and naval ships ${ }^{1}$, and enforcing its air space around controversial, man-made islands in the South China Sea. However, despite heavy investment in the military, the US has accrued a global network of military assets and built strong alliances ${ }^{2}$, which the Chinese currently cannot match.

Whilst China is the biggest threat to the US' superpower hegemony, we should also note that Russia has begun to reestablish itself as a global actor, in particular through military means. Russia's involvement in the Syria conflict has shown that it is prepared to take part in conflicts beyond its own front-door, but also the failure of Russia to fulfill its obligations under the Intermediate Nuclear Forces Treaty (INF) forced the US to withdraw from the Treaty in summer of 2019, further destabilizing global peace. Combined with the 2014 annexation of Crimea and

\footnotetext{
${ }^{1}$ For example, in September 2019 China launched an amphibious assault ship, which symbolizes its intent to modernize and strengthen its naval and military capabilities in the region.

${ }^{2}$ As we shall see later in section V, the President of the US is currently damaging some of these established alliances, which could weaken the US' position in certain regions.
} 
the subsequent war in the Ukraine, Russia is definitely emboldening its foreign policy. President Putin also invited Kim Jong-un to Russia for his first state visit in April 2019, which shows that the two leaders are also starting to build relations, even if nothing of weight was agreed in that summit.

The DPRK has also been a player in global changes. Having become a de facto Nuclear Weapon State (NWS) the DPRK has elevated its role in the region, in particular with regards to security issues. Whilst there is immense secrecy surrounding the exact assets possessed by the DPRK government, intelligence seems to believe that the DPRK's capabilities are growing. A report by the Council on Foreign Relations in 2019 emphasized the credible threat of the DPRK to the US, "Analysts estimate the Hwasong-15 has a potential range of 13,000 kilometers $(8,100$ miles) and, if fired on a flatter trajectory, could reach anywhere on the U.S. mainland." The same report also highlights the rapid progression of missile testing under the Kim Jong-un leadership, with figures showing that between 1984 and 1994, under Kim Il-sung, 15 tests were carried out, under Kim Jong-il's entire leadership only 16 tests were carried out, whereas thus far (up to October, 2019) under Kim Jong-un 105 tests have taken place. ${ }^{3}$ The North's credible nuclear leverage has clearly forced changes in the system. Even though China has officially started to support UN sanctions against the DPRK for its 'misbehavior', it is still clear that China is not bowing to US pressure and is using the DPRK to its own advantage. ${ }^{4}$ Indeed in June, 2019, The Diplomatreported that China and Russia blocked attempts made by the US in the UN to officially declare that North Korea had violated sanctions (Lederer 2019). Sino-DPRK and Russia-DPRK relations will also play a crucial role in determining the DPRK's foreign policy and current signs are that these relations are, on the whole, quite good.

Overall, it is clear that the system is moving towards a transition phase, with the US no longer holding the dominant position in international affairs. China is rapidly emerging as a global economic rival, and whilst still only regional at the present, its military is also shaping up to become a global force. Russia is similarly starting to flex its military muscles again after a period of "rest", although it is still not economically in a position of influence. These changes, along with the DPRK's defiance of international sanctions against its nuclear weapons program, reinforces Waltz's neorealist perspective that we are still in a state-centric world where the distribution of power determines foreign policy.

\footnotetext{
3 The DPRK since tested "large" missiles in November, 2019, and short-range missiles in March, 2020.

${ }^{4}$ In August, 2019, a UN Panel of Experts published a report on the extent to which the DPRK has violated international sanctions. Accessed at https://www.ncnk.org/sites/default/files/UN_POE_A ugust2019.pdf (October 24, 2019).
} 
In other words, the weakening of US dominance and the rise of the DPRK's ally, China, is enabling Kim Jong-un to follow his own foreign policy more aggressively. However, the changing global order did not erupt in late 2017, or early 2018, but rather these changes have been slowly emerging over the previous ten to twenty years. As such, it has been shown that there were no major, unexpected developments at the system level that could have impacted the DPRK's foreign policy U-turn, suggesting that either unit or individual level changes had a greater significance.

\section{UNIT LEVEL ANALYSIS}

In this section changes that have occurred at the national level will be discussed. As Waltz $(1959,82)$ mentions, certain governments which are considered to be "bad" often attempt to overcome their domestic "defects", in particular "the deprivations imposed by despots upon their subjects produce tensions that may find expression in foreign adventure." It is clear that the DPRK has been ruled over the past seven decades or so by a totalitarian regime that has highly restricted individual freedoms and would be considered "bad" in the western democratic sense of the word. Whilst that is true, there has been little change otherwise in the national system within the DPRK. The only major change has been that discussed in the section previously, which talked about the DPRK's advances in missile and nuclear technologies.

Kim Jong-un has been in power in the DPRK since 2011, during which time he has taken a firm grasp on power. Recent reports seem to hint that he is becoming more paranoid, with CNN reporting that Kim is now blocking out windows in "high-rise buildings in Pyongyang in what experts believe is an attempt to crack down on" ('Kim Jong Un Appear to Take Extreme Step Against Spying'). On the other hand, that would appear to follow standard procedure in the North, with secrecy having been the standard for the past seventy years. Fully understanding what happens within the North is therefore difficult, although if any major change had taken place it would have been discovered. As such, for the DPRK itself, we can say that on the unit level there has been no major factor that has had an influence on the drastic change in foreign policy in 2018.

In South Korea, oppositely, the domestic situation has been somewhat mired in controversy. Following Park Geun-hye's impeachment-discussed in more detail in the next section-the RoK's political system and society has been widely divided along partisan lines. The conservative right-wing party, to which former President Park belonged, has historically been less appeasing-could one even say 
more aggressive?- towards the North, often emphasizing reunification through absorption and anti-communist propaganda. ${ }^{5}$ One example was former President Lee Myung-Bak's 'Vision 3000' policy which reverted to a policy of reciprocity with the North, following a decade of functionalist engagement by Presidents Kim and Roh. ${ }^{6}$ Importantly, Kim and Roh were both left-wing, progressives who pursued policies of engagement and appeasement. As such, with the return to a left-wing progressive government under Moon Jae-in in mid-2017 this signaled an opportunity for the DPRK to once again benefit from a more favorable policy.

Under Moon Jae-in's administration the foreign policy has changed to a progressive approach that pursues closer ties with the DPRK, but at the same time has damaged relations with both the US and Japan. The US-RoK military alliance, which has guaranteed South Korea's security since the 1950s, is not as strong as it was, with Moon Chung-in, special advisor to Moon, declaring that "he would eventually like to see the U.S.-South Korea alliance end" (Friedman 2018, 'A Top Adviser to the South Korean President Questions the U.S. Alliance'). Kim Jong-un, the astute leader he is, has been subtly at times, and quite blatantly at others, trying to deepen the wedge between the RoK and US. In particular, during his address to the National Assembly in April, 2019, Kim stated that South Korea's governments should not mediate talks between the North and US, but instead should work directly with the North on matters such as reunification based on national sentiment. ${ }^{7}$ The use of Salami tactics here is clear.

Within South Korea's domestic political system there are still major differences and disunity in general. Millard (2019) discusses the lack of bipartisanship with regards to North Korea, noting that the DPRK may have sensed that with the return of the progressive government to office it would benefit from closer relations, just as it did when Kim Dae-jung and Roh Moo-hyun were in office. Based on the RoK's constitutional limit of one, five-year term in office for each President it is understandable that the DPRK would want to take advantage of the opportunity presented, given the chance that a conservative government could return to office in the next election. In South Korea's 2020 parliamentary elections former

5 For a detailed overview of South Korea's political developments and party reunification policies since 1948, see Kim Hakjoon. 2010. The Domestic Politics of Korean Unification: Debates on the North in the South 1948-2008. Korea: National Library of Korea

6 President Kim Dae-jung was famous for his 'Sunshine Policy' which essentially was a give-first, take later policy of economic aid to the North. In 2003, President Roh succeeded Kim and essentially followed the same policy, although the name was changed to the 'Peace and Prosperity Policy'.

7 For an English transcript of the speech, accessed at https://manage.thediplomat.com/ wp-content/uploads/2019/04/thediplomat-supreme-leader-kim-jong-un-makes-policy-speec h-at-first-session-of-14th-spa.pdf (October 26, 2019). 
defectors from North Korea, including former DPRK deputy ambassador to the United Kingdom, Thae Yong-ho, committed themselves to run for seats as conservatives. They have criticized the Moon administration for "cutting funding, ignoring human rights, and suppressing anti-Pyongyang activism" and will push to raise awareness of abuses happening in the DPRK that the Moon administration, they say, is ignoring (Shin and Cha, 'Defectors from North Korea run in South's elections to battle flawed policies'). In addition, the current administration has faced strong criticism for its proposed reforms, including lowering the voting age, implementing a new system of proportional representation, and establishing anti-corruption laws enforced through independent bodies. Whilst opposition parties vehemently attempted to prevent these reforms going through, the Moon administration has stuck to its proposals, defending them as reforms to further enhance democracy in the RoK. Its biggest defeat came with the resignation of President Moon's newly appointed justice minister, Cho Guk, who was ironically forced to stand down after claims of corruption emerged. Needless-to-say, disunity is rife in South Korean domestic politics on several fronts.

With regards to Japan-RoK relations, they are at an all-time low. The decline in relations has come about following the start of the Moon administration and these worsening relations are now affecting economic, political and security issues. With historical issues still unresolved Moon has pushed for Japan to apologize and compensate for colonial period damages, which has upset the Japanese administration. Whilst economic issues and trade disputes are serious, the bigger problem regarding security in the region arose when South Korea officially decided to withdraw from the General Security of Military Information Agreement (GSOMIA) in August, 2019. According to Stangarone (2019), "GSOMIA provided a direct line for South Korea and Japan to share intelligence on North Korea and other security issues in the region. The pact also helped South Korea and Japan cover gaps in their own intelligence gathering on North Korea." The proposed withdrawal meant that security in the region would have been potentially compromised. Indeed, following the announcement to not renew GSOMIA the DPRK tested short range missiles on several occasions, highlighting the lack of communication between the RoK and Japan. These tests hinted at differences in opinions between Japan and the US, with the New York Times reporting that Abe fully condemned the tests, whereas Trump was more willing to forgive the tests (Sanger and Broad 2019, NYT), although it should be stated that in general US-Japan relations are still good. ${ }^{8}$ In the face of criticism from several

\footnotetext{
${ }^{8}$ It should also be mentioned that under Abe, the Japanese government is working to amend its constitution in a move away from a pacifist one to a more defensive one. In particular, amending
} 
allies and domestic groups, the RoK government reversed its decision to leave GSOMIA in November, 2019, a decision that was welcomed by the US.

In the US itself, there is a strong domestic divide, following partisan lines, on foreign policy. A Pew research poll in early 2019 revealed that with regards to foreign policy "the U.S. public is divided over whether withdrawing U.S. troops from Syria is the right (43\%) or wrong (45\%) decision. Many Americans (65\%) do not think Trump has a clear plan for dealing with the situation in Syria; this includes a majority of Republicans (56\%) and an even larger majority of Democrats (91\%)" (Pew Research Center 'State of the Union 2019'). Schultz (2018, 8) gives a much more pessimistic view of the domestic view of foreign policy in the US, stating that the biggest threat to US foreign policy comes from domestic disunity based on Trump's "promoting an "America First" foreign policy that departs in significant ways from the policies that have underpinned U.S. global leadership over the last 70 years."

Whilst focusing on Trump's particular nationalistic view in that statement, Shultz also recognizes that over the preceding decades a clear partisan divide has appeared to the point where "disagreements now cut along party lines and hinder bipartisan cooperation. The disappearing center means that there are fewer conservative Democrats and liberal Republicans to broker deals across the aisle" (ibid., 11). Based on that assessment, whichever party controls Congress, in particular the Senate, will determine the direction of foreign policy, but for this paper's argument the crucial point was that has been the status quo for several decades. As it goes, the Republicans, between 2017-2018 controlled both the House and the Senate, and whilst the 2019-2020 session saw the Democrats take control of the House, the Republicans still hold a majority in the Senate. As long as party loyalty still holds, this means that through to 2020 the Trump-lead, Republican administration will follow a more traditional foreign policy, at least in theory. ${ }^{9}$ What has been seen during President Trump's time in office, however, is that Trump tends to follow his own ideas, with or without support from Congress or his advisors. This was highlighted by the Democratic Party voting for an impeachment of the President in late 2019 citing evidence that President Trump and his team had abused their privileged rights. In the end, the Senate

Article IX of the constitution, entitled 'Renunciation of War', is Abe's major objective as this would allow Japan to participate in more overseas military activities, as well as boost national defense.

9 Figures from congress.gov show that in 2017-2018, the Republicans had 252 seats in the House and 55 seats in the Senate, compared to the Democrats who had 204 and 49 seats, respectively. For the 2019-2020 period, Democrats control the House with 239 seats to 204, whilst Republicans hold the Senate majority with 53 seats to 46. See congress.gov, 'Members of the U.S. Congress'. Accessed at https://www.congress.gov/members?q=\%7B\%22congress $\% 22 \% 3 \mathrm{~A} \% 5 \mathrm{~B} \% 22116 \% 22 \% 5 \mathrm{D} \% 2 \mathrm{C} \% 22 \mathrm{cha}$ mber\%22\%3A\%22House \%22\%7D (October 22, 2019). 
voted in favor of the President.

When it comes to the DPRK, the political system has not seen any major change in recent years. Obtaining official information and policy is difficult in South Korea, and so determining the exact cause of Kim Jong-un's policy shift has been challenging. ${ }^{10}$ What has become more pressing, on the other hand, has been the economic situation in the DPRK and the effect of increasing sanctions on both the regime and the people. It is believed that the Hanoi summit failed, finishing fairly summarily, because the North demanded the removal of sanctions in order for negotiations on denuclearization to begin, but the US refused. Moreover, despite ever-increasing sanctions, by both the $\mathrm{UN}^{11}$ and US, unilaterally, many experts also reject the notion that sanctions are having a major negative effect on the North's economy. Kleine-Ahlbrandt, working for 38 North, states, "In 2019, after three years of "maximum pressure"-which includes unilateral US as well as UN sanctions-there are few signs of macroeconomic distress in North Korea" ('Maximum Pressure Against North Korea, RIP'). Silberstein analyzed the economic impacts of the sanctions and has determined that whilst the DPRK is suffering to a degree "no disaster seems to be looming in the immediate future" and more importantly "It is unlikely that the sanctions will result in social instability that truly threatens the regime's hold on power" (East Asia Forum 2019, 'The True impact of North Korean Sanctions'). In addition, the DPRK has developed several methods to overcome the sanctions and still import and export many prohibited goods, for example oil and coal. The August, 2019, report by the UN panel of experts provided evidence that the sanctions are being flouted regularly, making them ineffective, with oil being transferred from ship-to-ship in international waters, as an example.

To say that the sanctions have had no effect would be wrong. The sanctions imposed against the DPRK are clearly having an effect, although as one article in the South China Morning Post ('North Korea UN sanctions are hurting the vulnerable, aid workers say') discusses, the majority of sanctions end up hurting the vulnerable members of society and humanitarian aid has been falling significantly over the past few years "from US\$117.8 million in 2012 to US\$43.8 million in 2016”. The European Union's European Commission, for instance, has

10 Obtaining reliable, verifiable information on the DPRK's domestic political situation is also difficult. In researching this paper, official DPRK government websites, for example the website for the DPRK's Ministry of Foreign Affairs (www.mfa.gov.kp), as well as North Korean websites uriminzokkiri.com, kcna.kp, rodong.rep.kp, and naenara.rep.kp were blocked by the South Korean government, meaning that accessing direct information about the DPRK's official position is limited.

${ }^{11}$ For a full list of sanctions, see 'Security Council Committee established pursuant to Resolution 1718 (2006), UNSC. Accessed at https://www.un.org/securitycouncil/sanctions/1718 (March 20, 2020). 
stated that the sanctions are making it harder to provide aid to many people in the North, stating that sanctions "have made it increasingly difficult to make international bank transfers in to the country, which affects the functioning of humanitarian agencies" (European Commission 'North Korea (DPRK)'). With regards to the heavier sanctions on exports of coal, for instance, there also seems to be room for the DPRK to maneuver. Having said that, of course the DPRK does want to reduce or remove completely the damaging sanctions imposed upon it. As such, this would naturally lead to a more friendly foreign policy approach to persuade foreign leaders, namely Trump and Moon, on a more personal relationship basis to reduce sanctions. As such, the next section looks more closely at the individual level. Again, we can see that within the DPRK, unit level changes are less significant in determining foreign policy, since all actions have remained within standard parameters to those of previous years. Likewise, in the US, RoK and Japan the unit level changes discussed have not drifted significantly from standard practice over the previous decades, but have remained relatively consistent, implying that individual level changes have been the most inconsistent with standard practice. The more likely explanation for Kim's policy shift was his belief that he could manipulate Trump and Moon in to relieving sanctions, without having to compromise on nuclear weapons too much. Kim has no doubt learned from the downfalls/mistakes of various other leaders-Gorbachev, Gaddafi, and others. Kim's goal is not to achieve a hierarchical society with social classes, but rather to realize the completion of Juche ideology. As such, we can see the individuality of leadership becoming the main facet of analysis.

\section{INDIVIDUAL LEVEL ANALYSIS}

The major argument for using individual level analysis to understand the sudden détente from the DPRK in 2018 is that changes in the international and national level have been rather limited, consistent with previous changes and have not deviated from 'standard' trajectories, whereas major foreign policy shifts have come from leadership changes in the US and RoK, changes which have been implemented despite opposition from within the incumbent parties. The individual level is thus vital for understanding why Kim Jong-un made drastic changes to the DPRK's foreign policy, namely that he was taking advantage of favorable conditions. Returning to traditional realist theory, the role that people play in decision-making can cause sudden changes in policy, whether they be rational or irrational changes. 


\section{UNITED STATES FOREIGN POLICY UNDER DONALD TRUMP}

As mentioned earlier, Mingst and Arreguin-Toft (2017) offered three factors that affect foreign policy decision making; the state of the political institutions, institutional constraints, and the importance of the issue itself. Based on these criteria, it could be argued that all three are satisfied in the US, namely the current state of US domestic politics and the investigations into President Trump, the President's seemingly unawareness of constitutional constraints on his actions, and the "peripheral" nature of the DPRK's situation.

It can be argued that the US is in a mini-crisis, in which President Trump's actions and relations with other world leaders have been called into question. Donald Trump has been, from the start, a non-traditional President, having made his fame and fortune in the business world, not in politics, meaning that he is inexperienced in politics at both the domestic and international levels. This has made him vulnerable to attack and manipulation form various individuals, groups and organizations. Following his inauguration, Trump has threatened to withdraw from NATO, withdrawn from the Paris Climate Treaty, been accused of having conflicts of interest regarding his businesses, been endlessly questioned about his relationship with several Russian elites and their involvement in election rigging, including President Putin, and has recently been embroiled in a scandal involving Senator Joe Biden and his links with the Ukraine, leading to an impeachment process which he eventually came out of relatively unscathed. In addition, he has been severely criticized by both Democrats and Republicans for his decision to withdraw troops from Syria, leaving the Kurdish allies somewhat defenseless against possible attacks from Turkey. In a report by the Washington Post, the decision to withdraw US troops from Syria has led to "A cascade of criticism by current and former military officials", adding also that the decision has "thrust into plain sight internal debates over the military's role in foreign policy" (Ryan 'They are Livid'). In the same report, there are discussions about the role of military officials in decision-making, noting that the military should merely put into action Presidential decisions.

More specifically regarding the DPRK, in 2017, the DPRK's foreign minister, Ri Yong Ho, accused Trump of declaring war on the state. Addressing reporters outside of the UN, the foreign minister is quoted as saying, "Since the United States declared war on our country, we will have every right to make counter-measures, including the right to shoot down United States strategic bombers even when they are not yet inside the airspace border of our country. The question of who won't be around much longer will be answered then" (Borger and Siddiqui 'North Korea's foreign minister: Trump has declared war on our country'). This quote shows the hostility that existed between the two states in September, 2017, but 
what was more telling was the response of the White House to Ri's threat of military retaliation compared to President Trump's statement at the UN that the US "would "totally destroy" North Korea" if it attacked US military facilities or those of its allies; Then White house press secretary Sanders said that the US continued "to seek the peaceful denuclearization of the Korean peninsula" (ibid.). Whilst Defense Department spokesman Colonel Manning also said that the use of force would be a possibility in the face of North Korean fire, the situation highlights three distinct points; Firstly, that President Trump follows his own personal opinions and is willing to diverge from official administration policy, secondly, President Trump's lack of diplomatic etiquette and tendency to be irrational, and third, the DPRK's unchanging security stance.

There is a growing concern within the US that the President is undermining the values of the US and becoming too belligerent. In a report by Foreign Affairs, one reporter describes Trump; "The president has proved himself to be what many critics have long accused him of being: belligerent, bullying, impatient, irresponsible, intellectually lazy, short-tempered, and self-obsessed" (Cohen 'America's Long Goodbye'). Furthermore, President Trump seems to be isolating himself, in particular with his more recent foreign policy decisions. At a time when he needs to strengthen party support, he is doing the opposite, making irrational decisions, that leave his staunch defenders perplexed. Maynard (2019), in a report for $\mathrm{ABC}$ news, highlighted this with the reaction of Senator Graham to Trump's Syria decision, "South Carolina Republican Senator Lindsey Graham, a tireless defender of Trump since he took office in 2017, was infuriated by his decision to pull American personnel from Syria."

The pattern is starting to emerge of a President who disregards his Cabinet and pursues objectives on a personal belief system. As such, this also shows that Trump has no regard for the constitutional constraints that should check his power. The recent refusal by the Senate to impeach Trump may only strengthen this confidence. For the DPRK, I advocate that Kim Jong-un, a shrewd leader, recognized from very early on the personal traits of Trump and acted accordingly, taking advantage of the US President. In 2017, during Trump's first year in office, Kim Jong-un tested Trump by provoking the President and making threats to the US. Trump's rather quick, irrational responses showed Kim Jong-un that Trump was a lone wolf in the US administration and not a member of the Congressional system, for example in 2017 President Trump talked of an "armada" heading to the Korean Peninsula to deter the DPRK, although in reality the navy confirmed the fleet was "actually thousands of miles away heading in the opposite direction" (Gambino, Borger, and Weaver 2017). This episode was a telling sign to any leader, in particular a despot like Kim Jong-un, that the US was being led by an egotistical, 
uninformed man. Add to that the dis-jointed approach of the White House and Trump at the UN in September and it can be concluded that this is where the seeds of foreign policy change were very possibly sewn in the mind of Kim Jong-un.

Despite the harsh war of words on Twitter in 2017, by early 2018 Trump and Kim were preparing for a summit in Singapore-quite a remarkable turn-around, especially given that the US made no major change in policy towards the DPRK. Having started to build a personal relationship with President Trump following direct summits in Singapore and Hanoi, it would appear that Chairman Kim has managed to prolong this one-on-one relationship, with Trump declaring in mid-2019 that he and Kim were "in love." In a scathing attack against President Trump, the Atlantic wrote an article trying to reach out to Trump and get him to realize that he is being played by Kim.

The article went on, "Here was the ruthless totalitarian whom the American president has professed to admire and trust ("We fell in love") and whose latest missile tests Trump has doggedly downplayed, despite the concerns of his allies in Asia and his own advisers" (Friedman 2019). Trump, it seems, truly believes that he and Kim have a genuine relationship and that means that his judgment on foreign policy may be clouded. Given the history of deception by the DPRK's leadership-the stand-out example being the continued nuclear weapons development program, despite the 1994 Agreed Framework-and the fact that the US has made no concessions on sanctions nor reduced its military presence in South Korea, it is clear that Chairman Kim was trying to play on President Trump's irrational, narcissistic characteristics to get Trump to push for change without the support of Congress. That appears to have been confirmed with a thaw in the relationship from 2019 and most notably a return to more undiplomatic name-calling in December, 2019; Choi Son Hui, the DPRK's first vice-foreign minister, was quoted as calling "Donald Trump as a "dotard" after the US President revived the war words with North Korean leader Kim Jong Un by calling him "Rocket Man”" (Berlinger 'North Korea revives 'dotard' insult'). Since DPRK officials are known to follow strict policy-line, it is obvious that Chairman Kim has realized that he will be unable to change US policy just by courting Trump alone. Since May, 2019, the DPRK has also re-initiated its missile testing-albeit short-range missiles which are not included on the list of sanctions-following an 18-month period without testing, suggesting a return to militarism rather than diplomacy.

With the onset of a crisis in American politics and President Trump pushing the boundaries of his authority, it is clear that individual leadership since 2017 has played a major role in determining US foreign policy, in particular towards the DPRK. This argument can be reinforced by the fact that Donald Trump has 
said that he does not want another meeting with Kim Jong Un before the next Presidential election so that he can focus on the campaign to be re-elected. This is striking confirmation that Trump's priorities are based on his own selfish interests. Moreover, since the Korean peninsula is geographically distant from the US mainland, the problem could have been seen as a peripheral one. Despite the ever-developing and strengthening of the DPRK's warhead delivery systems-as discussed earlier-it is still relatively peripheral for the US, since the Korean peninsula lacks any natural resources that could threaten global trade, and the division of Korea is concretizing, meaning that any unexpected reunification is unlikely to occur. In simple terms, as a situation that does not demand, arguably, the US's full attention, Trump has more leeway to act as he sees fit. Indeed, the second summit in Hanoi, in February, 2019, highlighted that Trump felt sure of a positive outcome and proceeded with the meeting, despite his close advisors encouraging the summit to be delayed. Tisdall of The Guardian went as far as to describe the Hanoi summit as a "Trump vanity project" ('Trump was out of his depth in Hanoi').

\section{REPUBLIC OF KOREA}

With regards to the RoK, individuals may influence foreign policy based on the first criteria of Mingst and Arreguin-Toft, notably the development of the political institutions. In this instance, the RoK's democratic constitution is a relatively immature one, having only been enacted in 1987 and establishing the Sixth Republic. ${ }^{12}$ Based on its infancy, and the previous four decades of authoritarian regimes, the RoK is still undergoing a transition towards democracy and liberal freedoms, and hence can also be said to be somewhat unstable. This was very much highlighted by the impeachment of former President Park Geun-hye which showed that levels of nepotism and cronyism, as well as corruption, are still at relatively high levels. Kim $(2017,13)$ summarizes the scandal behind the impeachment of Park in an article for the Harvard International Review, in which she states, "News reports revealed that Choi used her close relationship with Park as leverage to seek billions of dollars from conglomerates, and was allegedly

12 The Constitution of the Republic of Korea was actually first established on July 17, 1948, in which it established South Korea as a democratic country with a market economy. However, that first constitution has been amended nine times, and at times the amendments have been quite striking. For example, during the leadership of President Park Chung-hee the Fourth Republic began following the seventh amendment, which created the Yushin constitution, extending the powers of the President. As such, I mention the most recent constitutional amendment as the date for the current constitution. For a full text of the current constitution, accessed at https://www.wipo.int/edocs/lexdocs/laws/en/kr/ kro61en.pdf (March 19, 2020). 
involved in Park's policy decisions despite being outside of the government". ${ }^{13}$ This statement highlights the corruption in the RoK government, as well as the tendency for decisions to be made by individuals. Singer $(1961,84,85)$ discusses this idea when he talks about the motivations and goals behind decision-making. He notes, "there is the more obvious issue of whether those who act on behalf of the nation in formulating and executing foreign policy consciously pursue rather concrete goals", adding later "the question would seem to distill down to whether man and his societies pursue goals of their own choosing". In Park's case, it would seem that she chose policies that were not necessarily in the national interest, but rather her and her acquaintances' interests.

Taking advantage of the scandal involving Park, Moon Jae-in swept into power on a wave of anti-corruption, domestic reform policies, but most importantly with a foreign policy that echoed strongly those of the former Presidents Kim Dae-jung (1998-2003) and Roh Moo-hyun (2003-2008). The 'moonshine' policy as it has come to be known, is seen by many as a return to foreign policy that heavily favors the DPRK and inter-Korean relations, at the cost of the RoK's other relations and individual freedoms. Tara O (2018), for example sets out the various ways in which President Moon, since coming to power in 2017, has begun to make changes that very much placate the DPRK, even if they cause domestic concern; the policies include having a unified Korean flag and women's ice-hockey team at the 2018 Winter Olympics, changing dates of historical events (such as National Liberation Day and Armed Forces Day) to ones that reflect the old unified Korea, not the RoK, changing history books to reflect a different series of events and political identity of the RoK, for example changing the RoK system from a 'liberal democracy' to a 'democracy', a further constitutional reform, for which "the constitutional reform draft was prepared in secret" (ibid., 10), and also new bills which Moon wants to introduced to expedite reforms through Congress. It is clear that President Moon has made changes that appease the DPRK leadership, but more importantly it appears that these reforms are also based on Moon's preferences and not the national desire.

Moon is well-known for having worked in the administration of President Roh Moo-hyun, during which time the UN was investigating DPRK human rights abuses. O (ibid., 14) cites the memoirs of Song Min-soon, former foreign minister under Roh, who states "Moon Jae-in made the decision to ask North Korea for their opinion before voting on the 2007 UN Resolution on North Korean Human

13 In this statement, Choi refers to the long-term friend of Park, Choi Soon-shil, whose father, Choi Tae-min, was described by the BBC as "a pseudo-Christian cult leader dubbed the 'Korean Rasputin'", who "became a close family friend and Park's mentor" (BBC, 'South Korea's Presidential Scandal'). 
Rights". Whilst such action could be seen as engaging with the North in a progressive policy, critics will note it as pandering to the North. This policy towards the DPRK must also be considered when analyzing why the DPRK changed its aggressive foreign policy to one of détente when the RoK changed its leadership to one so open to offering beneficial exchanges with the North. As with the timing, it appears that Kim Jong-un gave President Moon a 'test period' in 2017 during which Kim was able to assess the leadership style of Moon and the capability to implement his policies. By 2018, it was clear that Moon had embarked on a much more favorable rapprochement to the DPRK and combined with the developing administration it can be stated that Chairman Kim took advantage of the changing positions of the US's and RoK's individual leadership styles.

\section{PEOPLE'S REPUBLIC OF CHINA}

When it comes to China there is a clear distinction with the US and RoK, namely the fewer institutional constraints upon its leadership to make decisions. Whilst the communist system has always followed an authoritarian approach, with official party members making non-transparent decisions, it appears that the current leader, President Xi Jinping, has taken a much tighter grip on power, resulting in the ability to make even more unaccountable decisions.

In March, 2018, the Chinese constitution was amended, giving more attention and power to the President and widening the purview of the communist party in Chinese society. The most widely reported change was that of the term-limit for Presidents. As the South China Morning Post reported, "China's legislature voted almost unanimously on Sunday in favor of changing the country's constitution to remove presidential and vice-presidential term limits" (SCMP, 'China ends presidential term limits'). The reform allows President Xi to remain in office for life, technically, giving him almost full rein to do as he pleases, especially since his own ideology 'Xi Jinping Thought' was "also voted in to the Charter" (ibid.). The timing of this change is important because it coincides with the change in policy of the DPRK, which could be considered as being on the system or unit level, but it also shows that individual leaders are becoming much more powerful and, as such, if personal relations are strong then individual influence can determine foreign policies.

The relationship between Kim Jong-un and Xi Jinping can be seen as a key point. The pair met five times in 2018 and 2019, in particular before and after the DPRK-US summits with President Trump, as well as a visit to Pyongyang by Xi in June, 2019. Even though there have been tensions between the two, due to the DPRK's nuclear weapons program, it is clear that support for Kim Jong-un by Xi 
is invaluable in allowing Kim to follow his foreign policy objectives. For Kim and the DPRK elites, it is without doubt that he/they have complete authority in decision-making, with Kim often portrayed as a ruthless dictator who executes anyone who threatens his leadership.

Moreover, the relationship between President Xi and President Trump has been somewhat of a rollercoaster. In their first summit in the US, in March, 2017, the relationship between the two seemed to get off to a good start, with both exuding signs of mutual respect. Bader, Dollar and Hass ('US-China relations, 6 months into the Trump presidency') reported for Brookings on the importance that Donald Trump puts on building personal relationships, noting that the March summit "was well-conceived and well-executed. Trump came out with a genuine high regard and respect for $\mathrm{Xi}$, and $\mathrm{Xi}$ clearly values his personal relationship with Trump as well.” The developing relationship may have also swayed Kim Jong-un into moving away from a belligerent foreign policy towards a more peaceful one, as he may have wanted to reassure President $\mathrm{Xi}$ that the DPRK would not incite any trouble in the region causing tensions to rise between the US and China, in particular as China has supported more recent UN Security Council resolutions on DPRK sanctions. Of course, in more recent months the US-China relationship has devolved in to a trade war that will also play in to the hands of Chairman Kim.

As Rourke $(2008,67)$ mentions, individuals often make heuristic decisions, i.e. they follow generalizations of previous incidents, thus making irrational decisions. The appeasement of Hitler set a negative precedent, that being the "lesson" later leaders drew was that compromise with dictators only encourages them. It would appear, however, that certain leaders, namely Trump and Moon, disagree and, despite advice from their own advisors, they followed individual policies of appeasement with Kim Jong-un, policies that the DPRK leader was all-but-too-happy to accept. In this sense, the individual leadership styles have played a major role in determining foreign policy direction in the North with Kim Jong-un taking advantage of the opportunities presented to him. Arguably, this is the most significant change out of all three levels of analysis to have occurred in the short time preceding the DPRK's policy change. It is also the first time that we have seen Presidents in both the US and RoK simultaneously show respect and good will to the DPRK, which shows that in late 2017, early 2018 the 'first image' is the most important in this situation. 


\section{CONCLUSION}

The cause of foreign policy change in the DPRK does not carry with it a simple answer. Indeed, as with the cause of war debate, there is not one definitive factor, but rather several factors all working together at one time, creating the opportune time for détente. This paper has shown that on all three major levels of analysis-system, unit and individual level-there are explanations for why the DPRK regime embarked on a very public period of rapprochement. Of course, it is far too easy to simply conclude that there is not one single answer and as this paper has shown in the years 2017 and 2018 the individual relationships and policies of individual leaders appears to have been the major turning point for DPRK foreign policy at that time. In other words, the 'first image' has been the major driver of change and classical realism seems to be ever-present despite deepening globalization.

The international level has seen a change in global power distribution with a shift from US hegemony towards a bipolar system including China and a re-emerging Russia. The growth of China economically and militarily has cast a shadow over the security umbrella in the Northeast Asian region and has allowed the DPRK to advance its own foreign policy, even despite China's support for international sanctions. In addition, Putin's Russia has also slowly modernized its military and re-established itself as a major actor in European and Asian affairs, meaning that the former Cold War triangle of China-DPRK-Russia is once again emerging, giving Kim Jong-un more freedom. However, these changes have been decades in the making and cannot be specifically attributed to the sudden policy U-turn of Kim Jong-un in early 2018. As such, the system level is considered to be less relevant.

On the unit level we have seen that the DPRK is also benefitting from internal conflicts in both the US and South Korea, in which partisanship is becoming even more polarized and foreign policy is being determined according to the wishes of incumbent parties. In Japan, the government is also pushing for constitutional reforms that threaten not only regional security, but also relations with South Korea and the US. China, meanwhile, continues its erstwhile domestic policies that advance nationalism and promote its grip on power. However, as with the system level, the unit level changes have not been a rapid change in policy or process, but have been the continuation of existing situations and policies. Therefore, the unit level can also be said to be less significant to DPRK foreign policy change of a drastic nature.

On an individual level, far-reaching impacts have been felt. President Trump in the US has very much thrown conventional leadership out of the window when 
it comes to US foreign policy, and domestic policy as well. He has taken a narcissistic path, often to the disapproval and dismay of his closest advisors. In the RoK, President Moon has reverted back to the very pro-North Korean policies of his former political allies and Presidents Kim Dae-jung and Roh Moo-hyun. Moon has faced increasing criticism of his pro-North Korean policies, as well as domestic policies, furthering disunity in the South Korean congress, but he seems determined not to back down. The timing of these leadership changes and their favorable actions to the DPRK in 2018 point to a conclusion that individual level changes have had the greatest impact on DPRK foreign policy. Kim has tried to manipulate the leaders to relieve sanctions, which he knows state governments will reject, by befriending the two Presidents. When it appeared that the two Presidents would not offer sanction relief or other benefits the relationships cooled and the DPRK has returned to missile testing, a sign that Kim was using the two.

One of the biggest limitations to this paper has been the amount of official North Korea documents available. Due to restrictions imposed by the RoK government on entering North Korean websites, accessing official DPRK foreign policy objectives has been difficult. However, overall a clear pattern has emerged that on both the system and unit levels, the changes that occurred in 2017/2018 were not majorly different to the pre-existing conditions. The leadership policies and styles of Presidents Trump and Moon, on the other hand, created a stage where Kim could act out his agendas in order to persuade the two to implement reforms to benefit the DPRK. In future, leaders from all countries, in particular South Korea and the US, should be aware that the North Korean leadership pursues its interests on a diplomatic stage only when it feels conditions suit its objectives. If Chairman Kim feels that he cannot manipulate leaders to his advantage then he will not form a relationship. This manipulative behavior should be well-known to all diplomats and state leaders.

\section{REFERENCES}

Bader, Jeffery A., Dollar, David, and Hass, Ryan. 2017. "U.S.-China relations, 6 months in to the Trump presidency." Brookings (August 14). Accessed at https://www.brookings.edu/blog/order-from-chaos/2017/08/14/u-s-chin a-relations-6-months-into-the-trump-presidency/ (December 11, 2019).

BBC. 2018. "South Korea's Presidential Scandal." (April 6). Accessed at https:// www.bbc.com/news/world-asia-37971085 (October 23, 2019). 
Berlinger, Joshua. 2019. "North Korea revives 'dotard' insult after Trump's 'Rocket Man' comment 'displeased' Kim Jong Un.” CNN (December 5). Accessed at https://edition.cnn.com/2019/12/04/asia/north-korea-kimjong-un-intl-hnk/index.html (March 19, 2020).

Borger, Julian, and Siddiqui, Sabrina. 2017. "North Korea's foreign minister: Trump has declared war on our country." The Guardian (September 26). Accessed at https://www.theguardian.com/world/2017/sep/25/north-kor eas-foreign-minister-says-trump-has-declared-war-on-country (March 20, 2020).

CNN. 2019. "Kim Jong Un appears to take extreme step against spying." $C N N$ (October 18). Accessed at https://edition.cnn.com/videos/world/2019/ 10/18/kim-jong-un-high-rise-windows-north-korea-todd-dnt-tsr-vpx.cn n/video/playlists/around-the-world/ (October 23, 2019).

Cohen, Eliot A. 2019. "America's Long Goodbye: The Real Crisis of the Trump Era." Foreign Affairs. Accessed at https://www.foreignaffairs.com/articles/uni ted-states/long-term-disaster-trump-foreign-policy (October 22, 2019).

Congressional Research Service. 2019. "China's Economic Rise: History, Trends, Challenges, and Implications for the United States."

Council on Foreign Relations. 2019. "North Korea's Military Capabilities'. Accessed at https://www.cfr.org/backgrounder/north-koreas-military-ca pabilities (October 22, 2019).

Dukes, Paul. 2002. The Superpowers: A Short History. London \& New York: Routledge, 1-29.

European Commission. 2019. "North Korea (DPRK)." (October 17). Accessed at https://ec.europa.eu/echo/where/asia-and-pacific/north-korea_en (March 19, 2020).

Friedman, Uri. 2018. "A Top Adviser to the South Korean President Questions the U.S. Alliance." The Atlantic (May 17). Accessed at https://www.theatlantic. com/international/archive/2018/05/moon-south-korea-us-alliance/5605 01/ (October 24, 2019).

. 2019. "The Disturbing Logic of Trump's Lovefest with Kim Jong Un.” The Atlantic (June 1). Accessed at https://www.theatlantic.com/politics/ archive/2019/06/why-doe-donald-trump-keep-praising-kim-jong-un/590 830/ (October 22, 2019).

Gambino, Lauren, Borger, Julian and Weaver, Matthew. 2017. "White House all at sea over claims flotilla was heading to North Korea." The Guardian (April 19). Accessed at https://www.theguardian.com/us-news/2017/apr/18/ north-korea-us-aircraft-carrier-location-navy-donald-trump (December 10, 2019).

Gleditsch, Nils P., and Hegre, Harvard. 1997. "Peace and Democracy: Three 
Levels of Analysis." The Journal of Conflict Resolution 41(2), 283-310. Horowitz, Julia. 2019. "There are more wealthy Chinese than Americans for the first time." $C N N$ (October 21). Accessed at https://edition.cnn.com/2019/ 10/21/investing/china-wealth-americans/index.html (October 22, 2019). Jacobs, Ryan T. 2015. "International Relations: Theory on Four Levels of Analysis." Accessed at https://scholarlyresearchandarticles.wordpress.com/ 2015/05/01/international-relations-theories-on-four-levels-of-analysis/ (October 18, 2019)

Kim, Ashley. 2017. "Sewol Ferry Tragedy and Park Geun-Hye's Impeachment." Harvard International Review 38(3), 13.

Kleine-Ahlbrandt, Stephanie. 2019. "Maximum Pressure Against North Korea, RIP.” 38 North (October 7). Accessed at https://www.38north.org/ 2019/10/ skleineahlbrandt100719/ (October 25, 2019).

Lederer, Edith M. 2019. "Russia, China Block UN from Saying North Korea Violated Sanctions." The Diplomat(June 19). Accessed at https://thediplo mat.com/2019/06/russia-china-block-un-from-saying-north-korea-viola ted-sanctions/ (October 24, 2019).

Lee, Jeong-ho. 2018. "North Korea UN sanctions are hurting the vulnerable, aid workers say." South China Morning Post (June 26). Accessed at https:// www.scmp.com/news/china/diplomacy-defence/article/2152600/un-sa nctions-hurt-vulnerable-people-north-korea-ngos (December 10, 2019).

Leng, Sidney. 2018. "China ends presidential term limits, but what other changes were made to the constitution?" South China Morning Post (March 11). Accessed at https://www.scmp.com/news/china/policies-politics/article/ 2136740/china-ends-presidential-term-limits-what-other-changes (October 23, 2019).

Loriaux, Michael. 1992. "The Realists and Saint Augustine: Skepticism, Psychology, and Moral Action in International relations Thought." International Studies Quarterly36(4), 401-420.

Maynard, Micheline. 2019. "Donald Trump's Republican support is cracking, and impeachment will reveal his real base." $A B C$ (October 15, 2019). Accessed at https://www.abc.net.au/news/2019-10-15/donald-trump-sup port-cracking-impeachment-will-reveal-real-base/11599098(October 22, 2019).

Mexhuani, Burim. 2017. "The Foreign Affairs of a State is Based on Its Strength in the International System." European Journal of Social Sciences Education and Research 4(4), 322-325.

Millard, Andrew S. 2019. "A Study on How the Lack of Bi-partisanship has Affected South Korea's Policy on North Korea: Implications for Future 
Relations.” Korean Social Science Journal 46(2), 155-174.

Mingst, Karen A. and Arreguin-Toft, Ivan M. 2017. Essentials of International Relations (7th ed.). New York \& London: W.W. Norton \& Company, 180-207.

Morgenthau, Hans J. and Thompson, Kenneth W. 1985. Politics Among Nations: The Struggle for Power and Peace. $6^{\text {th }}$ Edition. New York: McGraw-Hill. O, Tara. 2018. "Moonshine Policy of Low-level Federation and the Potential Danger of North Korea-dominated Korean Unification." Paper presented at the Woodrow Wilson Center, February 14, 2018.

Pew Research Center. 2019. "State of the Union 2019: How Americans See Major National Issues.” (February 4). Accessed at https://www.pewresearch. org/fact-tank/2019/02/04/state-of-the-union-2019-how-amercans-see-m ajor-national-issues/ (October 22, 2019).

Rourke, John T. 2008. International politics on the world stage (12th ed). New York: McGraw-Hill, 64-100.

Ryan, Missy. 2019. "They are Livid: Trump's withdrawal from Syria prompts rare public criticism from current, former military officials.” Washington Post (October 20). Accessed at https://www.washingtonpost.com/world/ national-security/they-are-livid-trumps-withdrawal-from-syria-prompt s-rare-public-criticism-from-current-former-military-officials/2019/10/ 19/d9455f08-f1ba-11e9-8693-f487e46784aa_story.html (October 22, 2019).

Sanger, David E. and Broad, William J. 2019. "North Korea Missile Tests 'Very Standard' to Trump, Show Signs of Advancing Arsenal." New York Times (September 2). Accessed at https://www.nytimes.com/2019/09/02/world/asia/ north-korea-kim-trump-missiles.html (October 23, 2019).

Schuman, Michael. 2019. "Forget the Trade War. China is Already in Crisis." Bloomberg (January 17). Accessed at https://www.bloomberg.com/ news/articles/2019-01-17/forget-the-trade-war-china-is-already-in-crisis (December 10, 2019).

Shephard, Wade. 2016. "As Allies Keep Jumping Ship, Will Obama's 'Knee-Jerk Reaction' To The AIIB End With Trump?" Forbes (November 15). Accessed at https://www.forbes.com/sites/wadeshepard/2016/11/15/asallies-keep-jumping-ship-will-obamas-knee-jerk-reaction-to-the-aiib-en d-with-trump/\#25b7b8251c43 (October 23, 2019).

Shin, Hyonhee and Cha, Sangmi. 2020. "Defectors from North Korea run in South's elections to battle flawed policies.” Reuters (February 19). Accessed at https://www.reuters.com/article/us-southkorea-politics-de fectors/defectors-from-north-korea-run-in-souths-elections-to-battle-fl awed-policies-idUSKBN20D161 (March 20, 2020). 
Shultz, Kenneth A. 2018. "Perils of Polarization for U.S. Foreign Policy." The Washington Quarterly40(4), 7-28.

Silberstein, Benjamin, K. 2019. "The true impact of North Korean Sanctions." East Asia Forum (July 3). Accessed at https://www.eastasiaforum.org/ 2019/07/03/the-true-impact-of-north-korean-sanctions/ (December 11, 2019).

Singer, J. 1961. "The Level-of-Analysis Problem in International Relations." World Politics 14(1), 77-92.

Soltani, Fakhreddin, Naji, Saeid, and Amiri, Reza E. 2014. "Levels of Analysis in International Relations and Regional Security Complex Theory." Journal of Public Administration and Governance 4(4), 166-171.

Stangarone, Troy. 2019. "Korea's Dispute with Japan Spills into National Security." The Diplomat (August 27). Accessed at https://thediplomat. com/2019/08/koreas-dispute-with-japan-spills-into-national-security/ (October 23, 2019).

Statista. "Annual growth of the real Gross Domestic Product (GDP) of the United States from 1990 to 2018.” Accessed at https://www.statista.com/statistics /188165/annual-gdp-growth-of-the-united-states-since-1990/(October 20, 2019).

Tamaki, Taku. 2015. "Levels of Analysis of the International System". In: Kavalski, E. (ed). 2015. Encounters with World Affairs: An Introduction to International Relations. Farnham: Ashgate, 85-106.

Tisdall, Simon. 2019. "Trump was out of his depth in Hanoi. This failure is his greatest flop yet." The Guardian (February 28). Accessed at https://www. theguardian.com/commentisfree/2019/feb/28/trump-hanoi-failure-kim -advantage-north-korea-human-rights (October 24, 2019).

Waltz, Kenneth N. 1959. Man, The State and War: A Theoretical Analysis. London \& New York: Columbia University Press.

[Received Dec 11, 2019; Revised Mar 23, 2020; Accepted Apr 1, 2020] 